\title{
Student's Awareness Towards Corruption Cases in Indonesia
}

\author{
Edbert Rafael Tjandra ${ }^{1}$, Benny Cristian ${ }^{2}$, Paloma Blanca Elizabeth Sitompul ${ }^{3}$, Rosita Artauli \\ Silalahi ${ }^{4}$, Moses Glorino Rumambo Pandin ${ }^{5}$ \\ ${ }^{1,2,3,4}$ Faculty of Pharmacy, Airlangga University \\ ${ }^{5}$ Faculty of Humanities, Airlangga University
}

edbert.rafael.tjan-2021@ff.unair.ac.id, benny.cristian-2021@ff.unair.ac.id, paloma.blanca.elizabeth2021@ff.unair.ac.id, rosita.artauli.silalahi-2021@ff.unair.ac.id, moses.glorino@ fib.unair.ac.id

\begin{abstract}
Background : The current corruption case in Indonesia are severely problematic since it is normalized by society. As a response, the current agenda of the Indonesian government to tackle it is by raising awareness of youth towards Indonesia's corruption case. Aim : This study aims to knowing the importance of anti-corruption education and its applications among students. Method : The methodology of this study is the use of a qualitative survey on Faculty of Pharmacy students and interviews with representatives of students of the Faculty of Pharmacy. The population of this study is students of Airlangga University. The sample of this study is 52 students of class C the Faculty of Pharmacy Result : Students have awareness about corruption and even proposed that the current anti-corruption education is not enough to tackle corruption. Recommendation : The researcher suggests that students can be brave to campaign about the importance of anti-corruption education to the public. Limitation : The limitation of this study is that it is difficult to conduct research because in the online pandemic era, this results in delays in the research process.
\end{abstract}

Keywords: corruption, young generation, awareness

\section{INTRODUCTION}

Corruption has become a disease which lives in the flesh of our nation's life. Yet, it feels alive that our society is starting to normalize it. Our society normalizes the idea that corruption is a culture of the Indonesian government. As Indonesian, we can see this in our daily life when we watch current mainstream news reports that officials reported to be involved in a corruption scheme either on television, radio, social media, and internet, we would feel that we are not surprised when an official is involved in those schemes.

The current situation of the Indonesian Corruption case itself is severe. According to the 2020 corruption perspective index, Indonesia ranked 102 out of 180 countries with a score of 37 out of 100. This number itself is still under the average which is 43,4 . This data itself shows that Indonesia still has a lot of corruption cases and the damage itself is large. Therefore, we can see that there is an urgency of corruption cases in Indonesia itself. 
The number of cases of corruption and its normalization shouldn't be tolerated by our society. The major reason is because corruption will bring enormous destruction effects on Indonesia's nation's life especially on the economy and law. The existence of corruption will inhibit the economy's growth and investment. Corruption also creates a bad portrayal towards the government, resulting in ineffective policy making and distrust from the society (Rachmawati, 2021). Thes status quo would harm a major part of Indonesia's nation's life since the majority of the nation's life is dependent on the economy and law.

One of the major examples that we can use as a proof is the downfall of new order in Indonesia in 1998. The new order government which was led by Soeharto, was known for its major number of cases in corruption, collusion, and nepotism. The result of these high cases and no mechanism to control and punish such behavior is that the integrity of the country is questioned. Government received a lot of criticism and backlash from the society in the form of riots and protests by the students. The new order government tried to silence these students but with a rising case of corruption which impacted the economy resulting in the crisis, pushed the new order even further, resulting in a lot of backlash and questions from the society which finally brought down the new order.

Considering the fact that corruption has a high impact towards nation's life, we can conclude that there is an urgency on the corruption prevention and eradication. One of the important steps that a country is able to do to fight corruption is to educate their young generation who will run a nation in the future. By educating the young generation, a nation can build an individual with a strong moral. As a consequence, they will become good officers who create a good policy, aren't involved in corruption, and even take a step further to create transparency from the government towards society. The existence of the young generation in Indonesia is a way for Indonesia to change their nation's life especially in the case of corruption.

Such feelings and strong morals that are able to be taken by the young generation must start with an awareness towards the corruption case itself. When young generation become aware towards corruption case, it means that they are realizing about how severe can corruption case impact towards their nation's life and the current status quo is not progressive. These unprogressive status quo are marked by the high number of corruption cases which exist and the low corruption transparency index in Indonesia.

The current anti-corruption education mechanism is mainly through formal education. One of the major implementation of Anti-Corruption education method can be seen in the implementation of anti-corruption education through PENETRASI (Penanaman 9 Nilai 
Karakter Anti Korupsi) which has been implemented on the Urban Village Community of Jabungan (Pritaningtias et al., 2019). This kind of model of anti-corruption method can be seen also in classes of formal education either in elementary school, junior high school, senior high school, and university. The main emphasis of this model of education is on the 9 anti-corruption characters which are indoctrinated towards the student.

The other models of anti-corruption education are the socialization and implementation of Pancasila values. The main idea from the implementation of Pancasila value is that Pancasila has a high position in Indonesia state, namely the national personality, the source of identity, morality, and role models for the safety of the nation. Pancasila must be applied in various aspects of life to maintain the identity and personality of the nation. (Putri \& Pandin, 2019). The implementation of Pancasila value means a lot in a corruption case since one of the major points in Pancasila is the existence of equality and morals inside of each citizen of Indonesia which is our national identity. These principles of equality and morals are against corruption so the indoctrination of these values would help students to realize that corruption is against our national identity.

From the current status quo, we took a response towards the current corruption urgency and the existence of anti-corruption education. We held a survey where we studied the characteristics of the Indonesian young generation and their awareness towards corruption cases in Indonesia and its urgency. From this survey, we can evaluate the current regulation of anti-corruption education that was held by the government

\section{GAP REFERENCE}

According to the literature review that we conducted regarding the anti-corruption education on elementary school, high schools, and university students, we can see that the current research has explained how specific lectures, subjects, educational models, systems, and activities are related to indoctrination of anti-corruption principles. The attempt of extermination and its strategy has specifically been explained to solve this problem. But on the basis, corruption not only exists externally but it is also internally in every individual. Therefore, to solve corruption there must be a repair and correction on individuals. The current field approach and actual status quo of the young generation, especially college students, need to be elaborated. If we are able to elaborate this idea we can explain to college students the urgency of corruption. Therefore, in this research we proposed the solution to solve corruption outside the anti-corruption education, the effectiveness of anti-corruption education, the 
awareness of college students towards corruption, and the understanding of college students regarding the urgency of anti-corruption education.

\section{OBJECTIVE AND BENEFITS OF THE RESEARCH}

1. Knowing the right solution to eradicate corruption among students.

2. Knowing the importance of anti-corruption education and its applications among students.

3. Knowing the knowledge of students at Faculty Pharmacy Airlangga University Batch 2021 about corruption and the importance of anti-corruption education in Indonesia.

4. Knowing the solutions offered by students at Faculty Pharmacy Airlangga University Batch 2021 for the problem of corruption in Indonesia.

\section{QUESTION}

- According to the respondent, How deep is respondent knowledge regarding corruption?

\section{METHODOLOGY}

This Research was conducted by a qualitative method by describing the statements from respondents based on their experiences. This research is to describe the state of knowledge of the younger generation in the introduction and sensitivity to the problem of corruption. Questionnaires are designed to measure this based on data needs in answering the question formulation. Questionnaires also ensure the anonymity of respondents by asking for a consent that all data that are used will be presented without telling the name or any other private information of the respondent to ensure that responde felt safe and comfortable when filling in some question inside questionnaires. Respondents describe the problem in a short statement based on their knowledge and experiences.

The method of finding respondents is Cluster Random Sampling, only a group or class of people that is relatively heterogeneous. Respondents in this study involved college students from C-2021 class Faculty of Pharmacy, Airlangga University. This study was conducted for a total of 52 students. The technique of this research used a form that inserts some questions and scales. Primary data source is knowledge about corruption itself and the sources of that knowledge.

From that data we conclude the data by analyzing all the responses that describe several things around corruption from the form that we have designed. This analysis combined with reference specifically 40 journals. the reference guide and give point of view of the problem 
we try to analyze. The result becomes a narration that concludes all the points of view from responses and references.

Flow chart of this research are:

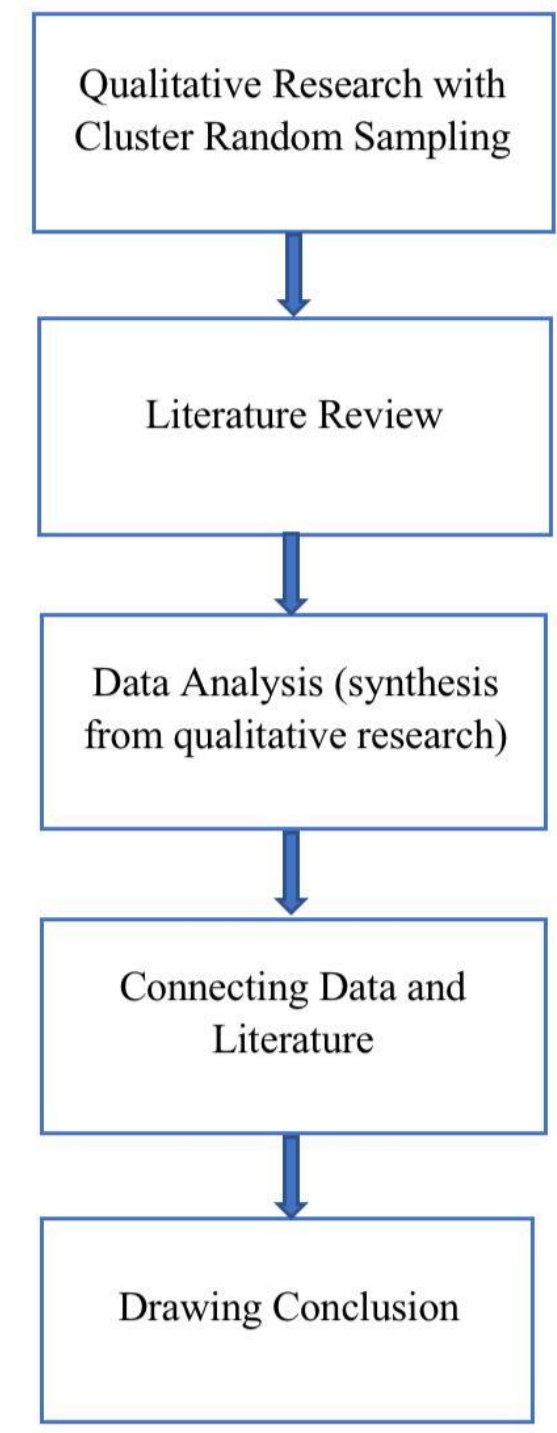

\section{DATA SOURCE}

The data source of our research comes from students of Faculty of Pharmacy Airlangga University. We choose student from institution that oversees our activity, that is Airlangga University. Specifically, we choose students of Faculty of Pharmacy in C Class Batch 2021 because the majority of us came from that class. We think the number of students used is sufficient to answer the problem formulation we want to develop and represent the population of the sample. 


\section{RESULTS}

We have received 52 responses on the questionnaire that we spread on the students of the Faculty of Pharmacy in Airlangga University. We ask several questions regarding student's understanding of corruption, the main media where they get information about corruption, the severity of corruption cases in Indonesia, and their opinion towards anti-corruption education in Indonesia.

\section{Table 1. General Response from Questionnaire}

\section{Response}

\section{List of Statement}

\begin{tabular}{|c|c|c|c|}
\hline $\begin{array}{l}\text { Strongly } \\
\text { Disaoree }\end{array}$ & Disagree & Neutral & Agree \\
\hline
\end{tabular}

Respondent believe that they

have deep knowledge regarding

0

1

10

32

9

corruption

Respondents believe that

corruption cases in Indonesia are

0

0

0

7

45

severe.

Respondents believe that anti-

corruption education is

0

0

0

1

51

Table 2. Respondent interest on following Indonesian Corruption News and Information

$\begin{array}{ccc}\text { Response } & \text { Yes } & \text { No } \\ \text { Quantity } & 40 & 12 \\ \text { Percentage } & 76,9 \% & 23,1 \%\end{array}$

Table 3. Main Media Used by Respondent to Obtain Information Regarding Corruption

$\begin{array}{lll}\text { Response } & \text { Quantity }\end{array}$

Television

27

$62,8 \%$ 


\begin{tabular}{lcc}
\hline Newspaper & 2 & $4,7 \%$ \\
\hline Online News & 25 & $58,1 \%$ \\
Social Media & 37 & $86,0 \%$
\end{tabular}

Note: Data are coming from Respondents who answered "Yes" on table 2 question and are able to choose more than one media.

\section{DISCUSSION}

According to the response from the questionnaire, a majority of the students are able to define what corruption is. The majority of them define that corruption itself is an illegal activity of taking a certain thing without the consent of the owner. The majority of the response also gives a clearance that corruption is mainly done by Government's officer. Some responses explain that corruption is not simply just in the typical government's case, but also in a broader way. For example, some responses defined that corruption is a case of taking time, quality, goods, abuse of power, not taking responsibility, and et cetera. Some also define that corruption can be done in a certain company or institution. Therefore, from this data itself we can conclude that the students of the Faculty of Pharmacy understand what corruption is and are able to define it.

The definitions that were defined by these students are correct. To prove these claims, we can compare the definitions that were defined by students with the definitions from literature. Novita Ilmaris and Arpangi (2021) on their article "Reform of Bureau of Public Services in Framework of Prevention \& Eradication of Corruption in Indonesia" defined corruption is an act that is very detrimental to the state, especially state finances which used as land for the enrichment of officials, their families, and cronies. Achmad Asfi Burhanudin (2021) also stated on his article "Strategi Penanaman Nilai-Nilai Anti Korupsi Pada Mahasiswa" that corruption is an act that are not in line with an officials duty in a country where the officials will got some individual benefit either it is status or money for themself or other people who have relationship with these officials. From both of these ideas, we can conclude that there is a similarity between the main definition of corruption that was brought by students, which is that corruption is an illegal activity of taking a certain thing without the consent of the owner mainly done by the officials.

The main factors where we can explain this capability of understanding is that the majority of the students are following the current corruption news. In fact $76,9 \%$ out of 52 
respondents claimed that they are following news about corruption. The main reason for this high number is that students are the younger generation that make use of a lot of technology. The technology that these younger generations use are the internet, social media, and online news which provide a lot of information regarding corruption. The use of technology itself also exists in their anti-corruption education where the students are given assignments to search for information regarding corruption. Therefore, we can see the main media for the younger generation to find information regarding corruption is television, online news, and social media.

The student understanding of the Indonesian corruption case severity itself are also in a high number. The majority of the response claimed that corruption brings a major impact towards our daily life. Students believe that corruption itself has corrupted a bunch of important aspects and even some that are against the principle of morality in Indonesia. For example, an incentive that was given by the government as a traditional social welfare system is corrupted. Students also believe that corruption has a bad impact towards the portrayal of Indonesian government either nationally or internationally. Therefore, we can say that the students of the Faculty of Pharmacy are aware of the urgency of corruption in Indonesia.

In Indonesia most students agree that our country's corruption has become the most critical problem. Most of the respondents mentioned that Indonesia has many corruption cases and most of them are the officers based on news that is circulating in the media. Corruption becomes more and more problematic because all of the citizens agree that corruption affects economic stabilization and development.

The main reason why such a phenomenon exists is that the current mechanisms are not really effective in dealing with corruption cases. There are some mechanisms that were taken by the Indonesian government such as legislative candidate right's limitation through constitution and court (Vantri, 2019), creation of constitution for prevention and eradication of money laundering (Fitriyana, 2019), and other actions. Those preventive and repressive measures are considered to be good. But, it can't cope with the clever and advanced corruption operandi. One of the major corruption operandi examples that we can see exist back in 2012 where it abused a system called hibah or gift which abuses power, bribery, and trading in influence are used with the cover as a gift. (Pradana, 2020). Beside the variative corruption operandi, the reason why corruption exists easily is the culture itself. Even if Indonesia could have an extensive anti-corruption mechanism, it would still be hard to tackle down since the law culture in Indonesia itself is patrimonial which is a power based on family who will abuse the current bureaucracy in order to do corruption, collusion, and nepotism (Odhy, 2021). 
This severely damaged status quo has been noticed by our younger generation. It is due to the existence of globalization and technology revolution in the 4.0 Industrial Revolution which digitized the major part of young generation daily life. Currently, The young generation or the current millennial generation are easily influenced by accessible information obtained from the internet and social media without any monitoring or information filtering (Putri \& Pandin, 2021). From this statement, we can characterize that the current younger generation are open with the information that exists and have a high curiosity. When they hear about corruption cases on television, social media, news, or any other media, they are willing to know about what corruption is and how severe it is already in Indonesia. This is due to the capability of mass media to influence what a certain group believes about a certain topic according to the Agenda Setting theory (Enggarratri, 2020).

Indonesia has tried to prevent these corruption cases in many ways, but again this problem isn't a simple and small problem. For example, giving anti corruption education in a formal class or daily life in an informal way. Respondent $98.1 \%$ agree that anti-corruption is important. Anti corruption education in Indonesia has become one of the best options that the government can do to prevent corruption in the early age. Most of the respondents think that anti-corruption in Indonesia still needs improvement. The biggest reason is that anti corruption education hasn't had a significant effect on each periode. In this condition, anti corruption education has improved from just an elementary subject to a college subject to make sure the anti corruption foundation will embed for the next generation. Respondents hope that anti corruption education does not try to embed the definition of corruption and how it affects Indonesia development. The point is the students need to understand implementing anti corruption so the next generation can view corruption become something really illegal for real. Many factors that affect someone's honesty but educating anti-corruption values for the young generation are parents and the education sector responsible.

The Solutions given by respondents are quite varied, such as socialization and education about what corruption is and the effect it has on the culprit and all Indonesian people, the value of being a chairman, and small things about discipline is the key to stop corruption. Implementation of anti corruption in the education period such as being honest and disciplined for small things for example time, shopping at "kantin kejujuran", and working in school or university organizations. Other, corruption law and anti-corruption enforcement must be evaluated. KPK in Indonesia needs to be supported and work harder to stop all corruption cases. The last, punishment and the corruption law that have been validated must be equality. So there isn't inequality that make corruption seem small in Indonesia. 
The KPK in carrying out corruption prevention uses the principle of supply and demand. Demand is applied to several strategies tactical related to prevention, strategy make improvements to the integrated focus area, institutionalization of the national integration system (SIN), support, development training center, strengthen the components of the political system, revitalize LHKN and gratuities, performance measurement prevention, effectiveness of budget planning. The strategy is then applied to achieve prevention against corruption so that the amount of corruption in Indonesia can be reduced though it will be very difficult to completely eliminate corrupt practices in Indonesia. Role success Corruption Eradication Commission in prevention and corruption because of the KPK have takeover authority investigation and prosecution carried out by the police and prosecutors KPK also has "Extraordinary" authority as a superbody in eradicating corruption. Powers conferred by law Number 30 of 2002 is actually country's efforts and strategies to support In total, the KPK's efforts to eradicate corruption in Indonesia.

Strategies for handling corruption or efforts to prevent corruption can be carried out through educational institutions or campuses, by obey rules and do this value such as, honesty, caring, independence, discipline, responsibility, hard work, simplicity, courage, justice. Students need to understand how important caring for yourself, others, environment, society and nation. Habituation of the practice of these values need to be concerned not only daily class but also all college activity. Neither informal nor formal activity in the whole term of study There are several ways to teach anti-corruption in college: Integrated models in courses, civilizing models, habituation of values in all activities and campus atmosphere, models outside of learning through extracurricular activities and combined models.

\section{CONCLUSION}

From the study and the research that we have done regarding Airlangga University student's awareness towards corruption cases in Indonesia we can conclude that students are able to define and understand what corruption is. They even understand the status quo of corruption cases in Indonesia which in their opinion, the corruption case in Indonesia is severe. The main source where the students use to find this information regarding corruption, which the majority of the students are following, are technology based media such as social media, online news, and television. These understandings also raise awareness on corruption urgency which are really severe and could cause a major problem in economy and policy-making.

In Indonesia, a major policy that the government takes to combat the case of corruption is through anti-corruption education. Anti-corruption education has been celebrated in our 
country and the majority of the respondents agree that this mechanism are important to combat corruption. But, the problem is that the current policy might be not enough since some respondents claimed that the current system of anti-corruption education hasn't shown a major impact and is still practical. Therefore, as a response the current students believed that to improve their anti-corruption education, there is a further step that the government should take. Fighting corruption not as simple as teaching students rules about corruption but also the value of anti-corruption itself. But, the most important is to make sure that value has become habitation in the whole student's daily activity when they are in college.

\section{REFERENCES}

Alfarisi, F. (2019). Pembaharuan Strategi Pemberantasan Korupsi Di Indonesia. Fairness and Justice: Jurnal Ilmiah Ilmu Hukum, 17(2), 120-132.

Bintarto, M. A. I., \& Zulhaj, R. A. A. (2021). Politik Hukum Penegakan Tindakan Korupsi Dimasa Pandemi Covid-19. Jurnal Ilmu Hukum, 10(2), 349-360.

Burhanudin, A. A. (2021). Strategi Penanaman Nilai-Nilai Anti Korupsi Pada Mahasiswa. SALIMIYA: Jurnal Studi Ilmu Keagamaan Islam, 2(2), 61-70. https://doi.org/https://doi.org/10.2906/salimiya.v2i2.337

Dermawan, H., Chandra, T., \& Tan, W. (2021). Penanaman Sifat Integritas dan Gerakan Anti Korupsi Melalui Sosialisasi di SMA Swasta Maha Bodhi Kabupaten Karimun. Jurnal Komunitas : Jurnal Pengabdian Kepada Masyarakat, 4(1), 28-36.

Enggarratri, I. D. (2020). Komitmen Pemberantasan Korupsi dalam Liputan Media. Communications, 2(1), $16-32$. https://doi.org/10.21009/COMMUNICATIONS.2.1.2

Firmansyah, R. A. (2020). Konsep Kerugian Perekonomian Negara Dalam UndangUndang Tindak Pidana Korupsi. Jurist-Diction, 3(2), 669. https://doi.org/10.20473/jd.v3i2.18211

Fitriyana, L. (2019). Pertanggungjawaban Partai Politik Dalam Tindak Pidana Pencucian Uang. Jurist-Diction, 2(4), 1319. https://doi.org/10.20473/jd.v2i4.14495 
Hatoguan Manurung, E., \& Heliany, I. (2020). Tindakan Preventif Yang Harus Dilakukan Dalam Menumbuhkan Pendidikan Antikorupsi Bagi Generasi Muda. Jurnal USM LAW REVIEW, 3(1), 219. https://doi.org/10.26623/julr.v3i1.2381

Hidayat, A. S. (2019). Pendidikan Kampus Sebagai Media Penanaman Nilai-nilai Antikorupsi Bagi Mahasiswa. SALAM: Jurnal Sosial Dan Budaya Syar-I, 6(1), 4354. https://doi.org/10.15408/SJSBS.V6I1.10498

Hikmah, S. N., \& Dewi, D. A. (2021). Meninjau Sejauh Mana Implementasi Nilai Pendidikan Karakter Melalui Pendidikan Kewarganegaraan di Perguruan Tinggi. Jurnal Kewarganegaraan, 5(2), 417-425. https://doi.org/https://doi.org/10.31316/jk.v5i2.1745

Hudiarini, S. (2020). Pendidikan Antikorupsi Bagi Mahasiswa Di Polinema Sebagai Upaya Preventif Tindak Pidana Korupsi. Seminar Nasional Gabungan Bidang Sosial - Polinema 2020, 53-63.

Ilmaris, N., \& Arpangi, A. (2021). Reform of Bureau of Public Services in Framework of Prevention \& Eradication of Corruption in Indonesia. Law Development Journal, 2(4), 634-646. https://doi.org/10.30659/LDJ.2.4.634

Junianto, J. D. (2020). Obstruction of Justice dalam Pasal 21 Undang-Undang No. 31 Tahun 1999 Tentang Pemberantasan Tindak Pidana Korupsi. Media Iuris, 2(3), 335. https://doi.org/10.20473/mi.v2i3.15208

Kesuma, N., \& Khairuman, K. (2020). Sikap Anti Korupsi Ditinjau Dari Budaya Malu dan Nilai Akademis Mahasiswa. JUSTITIA, 7(4), 811-818. https://doi.org/10.31604/justitia.v7i4.811-818

Latif, M. W., Adam, S., \& Suyanto, B. (2020). The chairman's leadership of corruption investigation management. Utopia y Praxis Latinoamericana, 25(Extra 2), 378-386. https://doi.org/10.5281/zenodo.3815272

Mahardika, M. D. G. (2020). Tinjauan Penerapan Sita Jaminan (Conservatoir Beslag) Dalam Tindak Pidana Korupsi. Jurist-Diction, 3(2), 499. https://doi.org/10.20473/jd.v3i2.18201 
Marta, R. F. (2019). Konsolidasi Gerakan Anti Korupsi Berbasis Akademisi Melalui Jurnal Integritas Dan Acs 2018. Jurnal Pengabdian Dan Kewirausahaan, 3(1). https://doi.org/10.30813/jpk.v3i1.1551

Muzaki, H. (2021). Illicit Enrichment dalam Tindak Pidana Korupsi. Jurist-Diction, 4(4), 1431. https://doi.org/10.20473/jd.v4i4.28455

Nugraha, X., Katherina, A. M. F., Agustin, W., \& Pamungkas, A. (2019). Non-Conviction Based Asset Forfeiture Sebagai Formulasi Baru Upaya Stolen Asset Recovery Tindak Pidana Korupsi Indonesia. Majalah Hukum Nasional, 49(1), 29-58. https://doi.org/10.33331/mhn.v49i1.92

Odhy, F. (2021). Perspektif Budaya Hukum Dalam Perkembangan Kasus Korupsi di Indonesia. $\quad$ Dharmasisya, $\quad 1(1), \quad 634-646$. https://scholarhub.ui.ac.id/dharmasisya/vol1/iss1/30

Parhan, M., Astuti, A., Yulianti Putri, A., Salmah Alia, D., \& Nur Oktapiani, T. (2020). Kantin Kejujuran Sebagai Penguji Spiritual Mahasiswa di Universitas Pendidikan Indonesia. Jurnal Pendidikan Ekonomi Indonesia, 1(2), 81-86. https://ejournal.upi.edu/index.php/JPEI/article/view/24860

Pradana, H. A. (2020). Tindak Pidana Korupsi Dalam Pemberian Dana Hibah. JuristDiction, 3(1), 153. https://doi.org/10.20473/jd.v3i1.17629

Pritaningtias, D. W., Barendriyas, A. S., Sabela, A. R., \& Utari, I. S. (2019). Implementation of Anti-Corruption Education Through Penetrasi Method (Penanaman 9 Nilai Karakter Anti Korupsi) for the Urban Village Community of Jabungan. Indonesian Journal of Advocacy and Legal Services, 1(1), 45-64. https://doi.org/10.15294/IJALS.V1I1.33752

Purwoleksono, D. E. (2019). the Applicability of Article 4 of Anti-Corruption Law and the Theory of Tort. Yuridika, 34(1), 21. https://doi.org/10.20473/ydk.v34i1.7552

Putri, G., \& Pandin, M. G. R. (2019). The Urgency Of Pancasila Values As A Form Of Millennial Generation Characther Education. Preprints, 3(2), 58-66. https://doi.org/10.20944/preprints202106.0301.v1 
Putri, R. E., \& Pandin, M. G. R. (2021). Analizing The Importance of Character Education for Millennial Generations in The Digital Era. Preprints, June. https://doi.org/10.20944/preprints202106.0348.v1

Putriyana, A., \& Rochaeti, N. (2021). The Impact of Enforcement of Corruption Law by the Corruption Eradication Commission after the Ratification of the Latest KPK Law. Jurnal Penelitian Hukum De Jure, 21(3), 299. https://doi.org/10.30641/dejure.2021.V21.299-310

Rachmawati, A. F. (2021). Dampak Korupsi dalam Perkembangan Ekonomi dan Penegakan Hukum di Indonesia. Eksaminasi: Jurnal Hukum, 1(1), 12-19. http://jurnal.umpwr.ac.id/index.php/eksaminasi/article/view/1185

Riwukore, J. R., Manafe, H., Habaora, F., Susanto, Y., \& Yustini, T. (2020). Strategi Pencegahan dan Pemberantasan Korupsi di Pemerintah Kota Kupang, Provinsi Nusa Tenggara Timur. Jurnal Masalah-Masalah Sosial |, 11(2), 2614-5863. https://doi.org/10.22212/aspirasi.v11i2.1556

Romadan, S. (2021). Peran Pendidikan Tinggi Hukum Dan Urgensi Mahasiswa Dalam Mewujudkan Hukum Yang Berkeadilan. Crepido, 3(1), 33-44. https://doi.org/https://doi.org/10.14710/crepido.3.1.33-44

Setia Darma Sinuraya, T., Widodo, \& Suwarno, P. (2021). Strategi Pemberantasan dan Pencegahan Korupsi di Indonesia dalam Masa Pandemi COVID-19. Jurnal Education and Development, 9(3), 125-130.

Sosiawan, U. M. (2019). Peran Komisi Pemberantasan Korupsi (KPK) Dalam Pencegahan dan Pemberantasan Korupsi. Jurnal Penelitian Hukum De Jure, 19(4), 517. https://doi.org/10.30641/dejure.2019.v19.517-538

Subkhan, E. (2020). Pendidikan Antikorupsi Perspektif Pedagogi Kritis. INTEGRITAS: $\begin{array}{llr}\text { Jurnal } & \text { Antikorupsi, }\end{array}$ https://jurnal.kpk.go.id/index.php/integritas/article/view/649

Vantri, A. V. (2019). Pembatasan Hak Mantan Terpidana Korupsi Sebagai Calon Anggota Legislatif Melalui Peraturan Komisi Pemilihan Umum. Jurist-Diction, 2(3), 793818. https://doi.org/10.20473/JD.V2I3.14290 
Victor, C., Marzuki, S., Pasalbessy, J. D., \& Patty, J. (2021). Aspek Melawan Hukum Pidana Terhadap Perbuatan Penyalahgunaan Wewenang Dalam Penyaluran Bantuan Sosial Di Masa PSBB kehilangan penghasilannya . Tindakan yang diambil oleh pemerintah yaitu membuat dan spiritual dimana dapat disimpulkan jika kebutuhan materi. TATOHI: Jurnal Ilmu Hukum, 1(7), 672-678. https://fhukum.unpatti.ac.id/jurnal/tatohi/article/view/662

Wibawa, D. S., Agustian, M., \& Warmiyati, M. T. (2021). Pendidikan Anti Korupsi sebagai Tindakan Preventif Perilaku Koruptif. Muqoddima Jurnal Pemikiran Dan Riset Sosiologi, 2(1), 1-18. https://doi.org/10.47776/mjprs.002.01.01

Wijaya, M. M. (2020). Sosialisasi Penanaman Mindset Pendidikan Anti Korupsi Pada Anak Usia Dini Berdasarkan Peraturan Walikota Bogor No. 28 Tahun 2019 Tentang Penyelengaraan Pendidikan Anti Korupsi. Pakuan Law Review, 6(2), 123-146.

Wirabhakti, A. (2020). Integrasi Nilai Anti Korupsi dalam Kurikulum Sekolah dengan Pendekatan Komisi Pemberantasan Korupsi. Jurnal At-Tadbir: Media Hukum Dan Pendidikan, $30(2)$, $173-183$. https://doi.org/https://doi.org/10.52030/attadbir.v30i2.62

Yunus, Y., Sarri, J., \& Syahir, S. (2021). Hilangnya Sifat Melawan Hukum Pidana Materil Dalam Tindak Pidana Korupsi Pasca Pengembalian Seluruh Kerugian Keuangan Negara. Media Iuris, 4(2), 243. https://doi.org/10.20473/mi.v4i2.25457

Zhafarina, A. N., \& Bantam, D. J. (2021). Pendidikan Antikorupsi sebagai Kebijakan Non-Penal dalam Upaya Pencegahan Tindak Pidana Korupsi. Media Syari'ah: Wahana Kajian Hukum Islam Dan Pranata Sosial, 23(1), 96. https://doi.org/10.22373/jms.v23i1.9497 